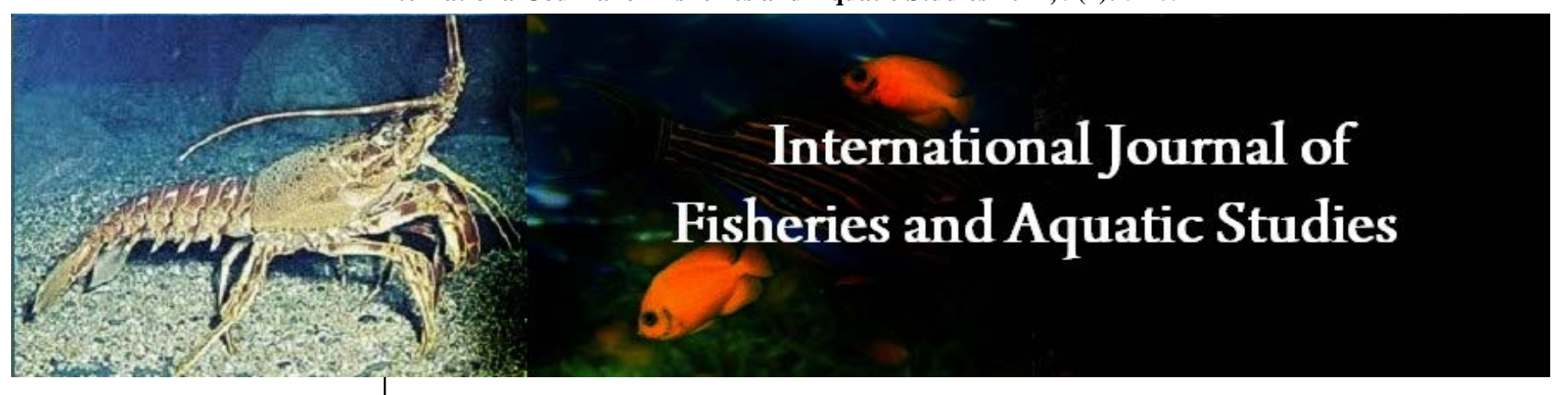

E-ISSN: 2347-5129

P-ISSN: 2394-0506

(ICV-Poland) Impact Value: 5.62

(GIF) Impact Factor: 0.549

IJFAS 2021; 9(4): 54-59

(C) 2021 IJFAS

www.fisheriesjournal.com

Received: 23-04-2021

Accepted: 26-05-2021

\section{Edilberto Rodrigues}

Núcleo de Ecologia Aquática e

Pesca da Amazônia and Grupo

de Ecologia Aquática, Cidade

Universitária Prof. José Silveira

Netto, Universidade Federal do

Pará, Avenida Perimetral, 2651,

Terra Firme, 66077-830, Belém,

PA, Brazil

\section{Fabiola Machado}

Núcleo de Ecologia Aquática e

Pesca da Amazônia and Grupo

de Ecologia Aquática,

Universidade Federal do Pará -

UFPA, Belém, Pará, Brazil

\section{Rory Oliveira}

Núcleo de Ecologia Aquática e Pesca da Amazônia and Grupo de Ecologia Aquática,

Universidade Federal do Pará UFPA, Belém, Pará, Brazil

\section{Marcelo Andrade}

Núcleo de Ecologia Aquática e

Pesca da Amazônia and Grupo de Ecologia Aquática,

Universidade Federal do Pará -

UFPA, Belém, Pará, Brazil

Corresponding Author: Edilberto Rodrigues

Núcleo de Ecologia Aquática e Pesca da Amazônia and Grupo de Ecologia Aquática, Cidade

Universitária Prof. José Silveira Netto, Universidade Federal do Pará, Avenida Perimetral, 2651, Terra Firme, 66077-830, Belém, PA, Brazil

\section{Target fishes from subsistence fishing in a riverine community from lower Pará River, Northern Amazonia}

\author{
Edilberto Rodrigues, Fabiola Machado, Rory Oliveira and Marcelo \\ Andrade
}

\author{
DOI: $\underline{\text { https://doi.org/10.22271/fish.2021.v9.i4a.2523 }}$
}

\begin{abstract}
The goal of the present study was to realize an inventory of target fish of the subsistence fishery from Genipaúba Village, Santa Bárbara do Pará, Brazil. The inventory was carried out during local fisheries throughout the main river between March and April 2018. The collections were performed with gillnets of 25 to $40 \mathrm{~mm}$ of mesh size, and length variable according to fisherman. The collected specimens were preserved in $10 \%$ formaldehyde and posterior wash in running water to preservation in $70 \%$ alcohol solution. In the laboratory all fish were identified to the current taxonomic species level, measured in standard length (cm), and in total weight (g), then cataloged in the fish collection of the Aquatic Ecology Group at Federal University of Pará (GEA-UFPA). Overall 19 fish species belonging to 13 families and five taxonomic orders were recorded. Most individuals were represented by species (family), the South American silver croaker Plagioscion squamosissimus (Sciaenidae), Yellowfin river pellona Pellona flavipinnis (Pristigasteridae), Mapará Hypophthalmus marginatus (Pimelodidae), Driftwood catfish Trachelyopterus galeatus (Auchenipteridae). Some important species for commercial trade were recorded as well, such as the Goliath catfish Brachyplatystoma filamentosum (Pimelodidae) and the Common snook Centropomus undecimalis (Centropomidae). In spite of the collections consisting of few species, the study is the first inventory of the most common fish species used by riverines from Pará River for subsistence.
\end{abstract}

Keywords: Neotropical region, taxonomic inventory, icthyofauna, fisherman

\section{Introduction}

Small and/or large scale fishing has a huge influence in the economic activities in the Amazon region ${ }^{[1]}$. Initially, this fishing was focused on the livelihood of riverside families and over time the focus has shifted to the consumer market ${ }^{[2,3,4]}$. In particular, in the Amazonian region, the fishery stands out in relation to the other Brazilian regions, due to greater diversity of exploited species, the highest fishery yield, just like in dependence of the traditional population on this activity ${ }^{[5,6,7]}$. The target of this fishery is fish for the subsistence of the riverside communities, where it is usually characterized by the participation of few fishermen who use few kinds of fishing gear such as gillnets and/or castnets, mainly due to its easy handling and maintenance ${ }^{[8-42]}$. Whether for subsistence or fish trade, fishermen generally use small boats due to the easy navigation into small stretches of river, lowland areas and other habitats of difficult access, but the small boats make limited productions ${ }^{[9]}$. The impediment of small storage, the cheap fish are sold at very low cost to make it easy to sell or discarded in order to store species with greater commercial value only ${ }^{[10]}$. Additionally, the fish surplus is traded, which is the main actor in this process is the "middlemen" ("atravessadores" in Portuguese) who mediate the sale seeking the markets of urban centers ${ }^{[11,12]}$.

In addition to fishing aimed for protein consumption in the Amazon, ornamental fishing stands out, which is a modality focused on capturing small fish species destined for aquariums ${ }^{[13,14]}$. In some regions it is exclusively artisanal, developed by the traditional knowledge of fishermen called "piabeiros" [ 15]. Among the consumer markets such as Japan, USA, and Germany stand out ${ }^{[16,17]}$. However, the target species of this type of fishery have high mortality rates, due to stress of capture, management and conservation until the final destination, so the capture is characterized by high abundances. 
The knowledge status about fish fauna destined for trade is generally derived from surveys of fishing landings, which provides a limited insight of them ${ }^{[18,19]}$. In this way, surveys of the fish fauna in locu better contribute with the knowledge of species with commercial value, destined for subsistence, and ornamental species [20, 21]. It is worth mentioning that fishing in the Amazon basin has been a recurring subject for the scientific community and, especially, in its estuarine stretch due to the high increase of recruits to fishery stocks ${ }^{\text {[22, }}$ $23,24,25]$. For this, the estuarine zones are considered the high priority areas for conservation and protection, thus guaranteeing fisheries viability for future generations ${ }^{[26,27]}$. In this context, the aim of the present study was to contribute with the knowledge of ichthyofauna of the main tributaries of the Pará River in Marajó Bay, Northern Brazil.

\section{Material and Methods}

The study was carried out in tributaries of the Pará River, near to the Genipaúba village $\left(01^{\circ} 13^{\prime} 25\right.$ "S e $\left.48^{\circ} 17^{\prime} 40^{\prime \prime} \mathrm{W}\right)$ in the Belém municipality $\left(1^{\circ} 27^{\prime} 18^{\prime S}\right.$ e $\left.48^{\circ} 30^{\prime} 9^{\prime \prime} \mathrm{W}\right)$. The city is located in the Estuary of the Marajó Bay (Fig. 1) with tributaries such as the Furo da Marinha River in Mosqueiro Island ${ }^{[28]}$. The region represents the highest precipitation between January and June, and the lowest between July and December. Besides that, this Estuary is characterized by a transition zone between fluvio-marine (i.e., salinity between 5 to 18), where the semidiurnal tide effect extends for several kilometers upstream river [29, 30, 31]. The predominant vegetation is mangrove of Rhizophora mangle L., Avicennia germinans (L.) L. and Conocarpus erectus L. ${ }^{[32] .}$

Samples were carried out during March and April 2018 in cooperation with local fishermen and at two points along the estuaries of Ceará and Tauá River. Fish were caught using gillnets of three different mesh sizes (25, 30 and $40 \mathrm{~mm}$ stretch mesh size), and to better capture fish species, gillnets were placed at river banks during $12 \mathrm{~h}$ on average (with verification every $6 \mathrm{~h}$ ). The fresh samples were immediately chilled in ice on site and fixed with $10 \%$ formalin solution upon arrival at the laboratory and deposited in the ichthyological collection of the Aquatic Ecology Group at Federal University of Pará (institutional catalog code GEA available in Table 1). Fish identification was based on specific literature ${ }^{[33,34,35]}$, and individually measured (standard length SL, and total length, TL) to the nearest $0.1 \mathrm{~cm}$ and weighed (total wet weight, $\mathrm{W}$ ) at a precision of $0.1 \mathrm{~g}$. The fish species were classified according to their trophic guild (TG) following ${ }^{[36]}$ and ${ }^{[37]}$ as: zooplanktivore (ZP), detritivore $(\mathrm{DV})$, piscivore $(\mathrm{PV})$, zoobentivore $(\mathrm{ZB})$, herbivore $(\mathrm{HV})$, oportunistic/omnivore (OP), piscivore/zoobenthivore (PV/ZB), and insectivore (IS). Additionally, they were classified according to estuarine use (EU), [37] as: marine stragglers (MS); marine migrants (MM); estuarine species (ES); freshwater migrants (FM), and freshwater stragglers (FS).

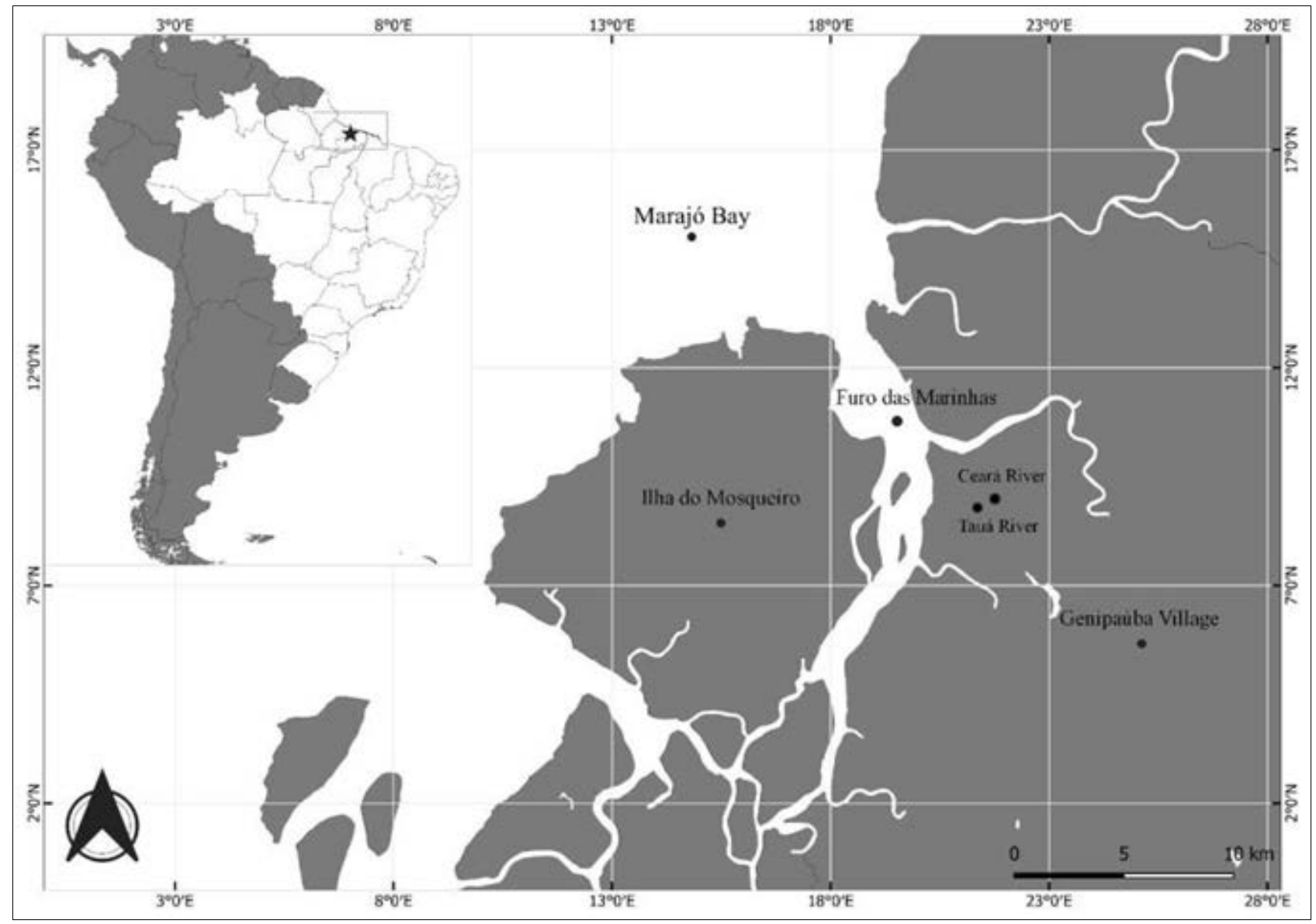

Fig 1: Study area in Ceará and Tauá Rivers, Santa Bárbara do Pará at Marajó Bay, Brazil.

\section{Results}

Overall, 91 specimens representing 19 different fish species belonging to 14 families and five orders were captured by artisanal fishermen in estuaries of Ceará and Tauá Rivers
(Table 1). The most diverse order was Siluriformes (six families and nine species collected), followed by Perciformes (three families and four species) (Table 1).

The order Siluriformes was best represented in our study (40 
$\%$ ), followed by the orders Clupeiformes (20\%), Perciformes (20\%), and others (20\%) (Fig. 2). The Scianidae was the best represented family (34.1\% of specimens captured), followed by the families Aspredinidae (13.2\%) and Curimatidae (13.2 $\%$ ), other families corresponded to $40 \%$ (Fig. 3).

Of the all caughted species, a total of 10 are consumed by fishermen in the region and are also commercialized: $T$. angulatus, P. atherinoides, B. bagre (also used as bait for the fishery of C. acoupa - pescada-amarela), H. marginatus, $\mathrm{H}$. platyrhynchos, T. galeatus (important to local consumption due to the large size), P. auratus, P. squamosissimus, B. filamentosum, and C. undecimalis. Five species are considered to be of ornamental importance: S. trigonocephalus, Hypostomus sp., H. plecostomus, G. proximus, and A. anablepis (see photographs of some captured species in Fig. 4). Species of no importance for consumption and/or ornamental market were P. amazonica, P. flavipinnis, A. tibicen, and L. grossidens, they are usually used as bait to catch other fish. Considering estuarine use (EU) for each point of sample, were found more species freshwater stragglers (FS) totaling eight species and in sequence seven estuarine species (ES) from two trophic categories which were seven zoobentivore (ZB) and four piscivore/zoobenthivore (PV/ZB) (Table 1).

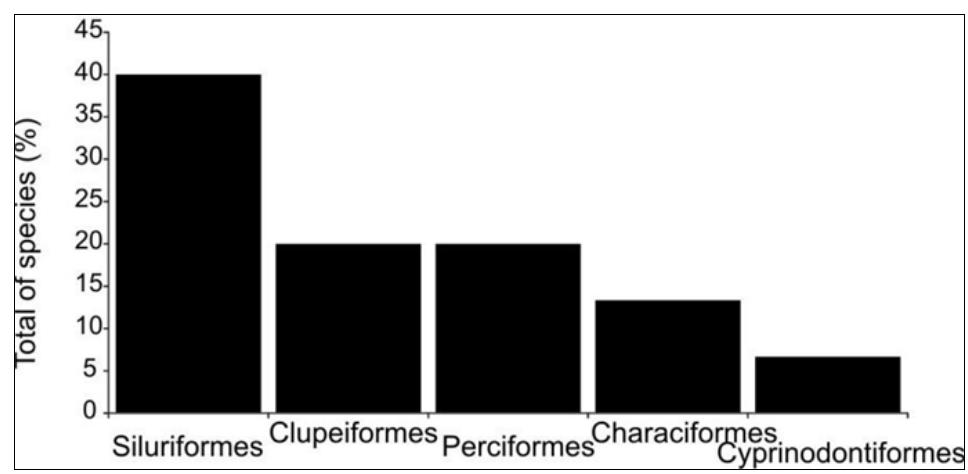

Fig 2: Percentages of the total number of sampled species in each order from Ceará and Tauá rivers, Santa Bárbara from Pará at Marajó Bay, Brazil.

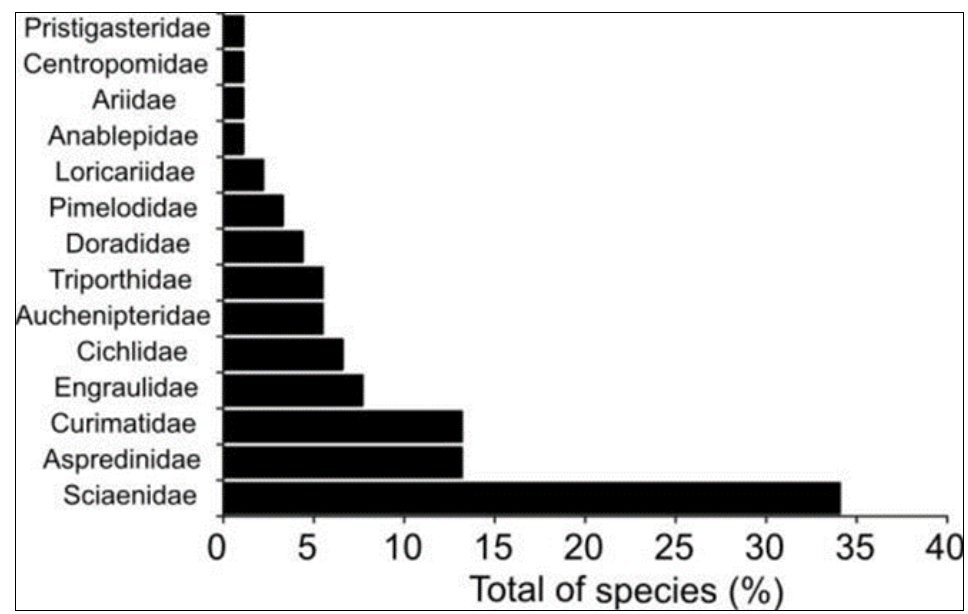

Fig 3: Percentages of the total number of sampled species in each family from Ceará and Tauá rivers, Santa Bárbara from Pará at Marajó Bay, Brazil.

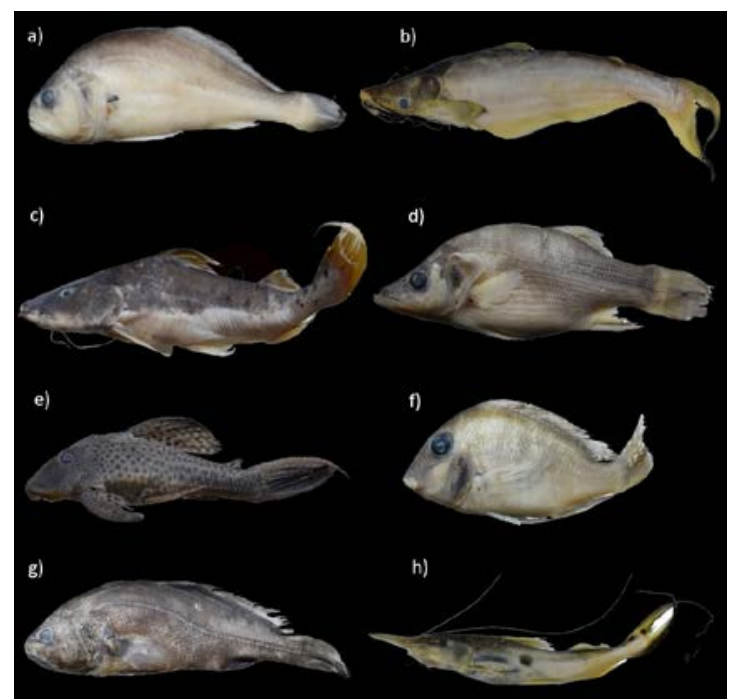

Fig 4: Some fish species representative from Ceará and Tauá rivers, Santa Bárbara from Pará at Marajó Bay, Brazil. a) Plagioscion squamosissimus, b) Hypophthalmus marginatus, c) Brachyplatystoma filamentosum, d) Centropomus undecimalis, e) Hypostomus plecostomus, f) Geophagus proximus, g) Plagioscion auratus, and h) Hemisorubim platyrhynchos. 
Table 1: Taxonomic list, trophic guild (TG), estuarine use (EU), number of individuals (N), standard length (SL), total length (TL), and weight (W) of the samples from Ceará and Tauá rivers, Santa Bárbara from Pará at Marajó Bay, Brazil.

\begin{tabular}{|c|c|c|c|c|c|c|c|c|}
\hline Orders/Family/Species & Common Name & TG & EU & $\mathbf{N}$ & SL (cm) & TL (cm) & W (g) & Voucher \\
\hline \multicolumn{9}{|l|}{ Characiformes } \\
\hline \multicolumn{9}{|l|}{ Curimatidae } \\
\hline $\begin{array}{c}\text { Psectrogaster amazonica (Eigenmann \& } \\
\text { Eigenmann, 1889) } \\
\end{array}$ & Branquinha & $\mathrm{D}$ & FS & 12 & $12.5-18.5$ & $16-22.5$ & $50-120$ & GEA 7333 \\
\hline \multicolumn{9}{|l|}{ Triporthidae } \\
\hline $\begin{array}{c}\text { Triportheus angulatus (Spix \& Agassiz, } \\
\text { 1829) }\end{array}$ & Sardinha-papuda & $\mathrm{ZB}$ & FS & 5 & $17.5-23$ & $21-28$ & $65-145$ & GEA 7336 \\
\hline \multicolumn{9}{|l|}{ Clupeiformes } \\
\hline \multicolumn{9}{|l|}{$\begin{array}{c}\text { Engraulidae } \\
\end{array}$} \\
\hline $\begin{array}{c}\text { Lycengraulis grossidens (Spix \& Agassiz, } \\
1829)\end{array}$ & Sardinha & $\mathrm{ZB}$ & ES & 5 & $8.5-11$ & $10-13$ & $10-20$ & GEA 7338 \\
\hline \multicolumn{9}{|l|}{ Pristigasteridae } \\
\hline Pellona flavipinnis (Valenciennes, 1837) & Sarda & $\mathrm{PV}$ & FM & 1 & 26 & 32 & 265 & GEA 7339 \\
\hline $\begin{array}{c}\text { Pterengraulis atherinoides (Linnaeus, } \\
1766)\end{array}$ & Sardinha & $\mathrm{PV} / \mathrm{ZB}$ & ES & 2 & $12-12.5$ & $14.5-15.5$ & $20-20$ & GEA 7349 \\
\hline \multicolumn{9}{|l|}{ Cyprinodontiformes } \\
\hline \multicolumn{9}{|l|}{ Aanablepidae } \\
\hline Anableps anableps (Linnaeus, 1758) & Tralhoto & $\mathrm{HV}$ & ES & 1 & 13 & 16 & 40 & GEA 7343 \\
\hline \multicolumn{9}{|l|}{ Perciformes } \\
\hline \multicolumn{9}{|l|}{ Centropomidae } \\
\hline Centropomus undecimalis (Bloch, 1792) & Robalo & $\mathrm{PV} / \mathrm{ZB}$ & ES & 1 & 26 & 30 & 425 & GEA 7341 \\
\hline \multicolumn{9}{|l|}{ Cichlidae } \\
\hline Geophagus proximus (Castelnau, 1855) & Acará & OP & FS & 6 & $10.5-13$ & $12.5-16$ & $40-75$ & GEA 7335 \\
\hline \multicolumn{9}{|l|}{ Scianidae } \\
\hline Plagioscion auratus (Castelnau, 1855) & Pescada-preta & $\mathrm{ZB}$ & FS & 1 & 18 & 23.5 & 130 & GEA 7342 \\
\hline $\begin{array}{c}\text { Plagioscion squamosissimus (Heckel, } \\
1840 \text { ) }\end{array}$ & $\begin{array}{l}\text { Pescadinha ou Pes- } \\
\text { cada-branca }\end{array}$ & PV & FM & 30 & $15.5-25$ & $19.5-28.5$ & $65-210$ & GEA 7334 \\
\hline \multicolumn{9}{|l|}{$\begin{array}{c}\text { Siluriformes } \\
\end{array}$} \\
\hline \multicolumn{9}{|l|}{ Aspredinidae } \\
\hline Aspredinichthys tibicen (Temminck,1840) & Rebeca & ZB & ES & 12 & $16.5-25.5$ & $20-26.5$ & $20-40$ & GEA 7332 \\
\hline \multicolumn{9}{|l|}{ Ariidae } \\
\hline Bagre bagre (Linnaeus, 1766) & Bagre & $\mathrm{PV} / \mathrm{ZB}$ & MM & 1 & 25.5 & 30.5 & 300 & GEA 7344 \\
\hline \multicolumn{9}{|l|}{ Pimelodidae } \\
\hline $\begin{array}{l}\text { Brachyplatystoma filamentosum } \\
\text { (Lichtenstein, 1819) }\end{array}$ & Filhote & PV & FM & 1 & 27 & 35.5 & 305 & GEA 7340 \\
\hline $\begin{array}{c}\text { Hypophthalmus marginatus } \\
\text { (Valenciennes, 1840) }\end{array}$ & Mapará & $\mathrm{ZP}$ & FM & 1 & 28 & 35 & 115 & GEA 7348 \\
\hline $\begin{array}{l}\text { Hemisorubim platyrhynchos } \\
\text { (Valenciennes, 1840) }\end{array}$ & Sorubim & $\mathrm{ZB}$ & MS & 1 & 24 & 38 & 125 & GEA 7346 \\
\hline \multicolumn{9}{|l|}{ Loricariidae } \\
\hline Hypostomus sp. & Acari & ZB & FS & 1 & 14 & 18 & 105 & GEA 7350 \\
\hline $\begin{array}{c}\text { Hypostomus plecostomus (Linnaeus, } \\
1758 \text { ) }\end{array}$ & Acari & $\mathrm{ZB}$ & FS & 1 & 16 & 22 & 110 & GEA 7345 \\
\hline \multicolumn{9}{|l|}{ Doradidae } \\
\hline Lithodoras dorsalis (Valeciennes, 1840) & Bacu & $\mathrm{HV}$ & FS & 3 & $12-14$ & $14-17$ & $40-40$ & GEA 7337 \\
\hline \multicolumn{9}{|l|}{ Auchenipteridae } \\
\hline $\begin{array}{c}\text { Trachelyopterus galeatus (Linnaeus, } \\
1766 \text { ) }\end{array}$ & Cachorro de padre & $\mathrm{PV} / \mathrm{ZB}$ & FS & 5 & $14-17$ & $15.5-18.6$ & $70-160$ & GEA 7347 \\
\hline
\end{tabular}

\section{Discussion}

The stretches of river sampled had the predominance of the order Perciformes, followed by Siluriformes, Characiformes, Clupeiformes and Cyprinodontiformes. Since the abundance and richness of species can change according to the methodology used at the time of collection, in the effort of capture and period of the day and year ${ }^{[19,11]}$. In this study, the fishing gear used (i.e., gillnets) was just that owned by the local fishermen. They use it due to their caught efficiency. However, this made it possible to observe which species are commonly caught due to higher selectivity of the fishing gear, because fishermen do not use a wide variety of meshes and also do not use more gears, such as longline, gillnets, among others.

Among the 14 families captured, the most representative species in terms of abundance was P. squamosissimus known as "South American silver croaker" belonging to the family Sciaenidae. The abundance of this species was monitored throughout the study. The reproduction of the species occurs throughout the year, characterizing spawning with two annual peaks, between April and June in wet season, and between August and September in dry season ${ }^{[25,38]}$. In the Amazonian region, this species has high commercial value in both freshwater and estuarine fisheries ${ }^{[39] .}$

According to the fishermen's reports and based on the observed analysis of the samples, it was noticed that each type of mesh captures a specific type of fish, the $25 \mathrm{~mm}$ meshes capture small species, which in most cases do not if it has a commercial value. It was also observed the capture of many juvenile fish, such as B. filamentosum captured during this 
study, which has high commercial value as an adult.

Estuarine habitats are used as breeding and nursery areas for many species of migratory fish ${ }^{[27,40]}$. This fact is corroborated by the presence in juvenile catches of $\mathrm{B}$. filamentosum and $\mathrm{C}$. undecimalis. These species are commonly found entering the estuaries, when salt variations are favorable, usually during periods of low rainfall ${ }^{[39,41]}$, seed dispersal species are more common during the rainy season, for example the species Lithodoras dorsalis which was collected in this study ${ }^{[42]}$

It was possible to observe during this study that the high presence of mangrove trees (e.g., A. germinans) and typical lowland percussion vegetation (e.g., Machaerium lunatum), showed high divergence in relation to habitats with less vegetation. In these areas, the capture of juvenile and adult fish of commercial value was highlighted by fishermen as essential areas for the community's subsistence.

In general, our study presents pioneering information for stretches of tributaries of the Marajó Bay, characterizing the main target species for the community's own consumption and trade, as well as basic information regarding the use of fluvial-estuarine areas by these species. Such observations are important for the development of conservation and management plans for these fish species. In addition, future studies should take into account a holistic approach to the analysis of iconic communities in different habitats in these fluvial-estuarine zones, still considering spatial and temporal variables, habitat connectivity, and recruitment of larvae.

\section{Acknowledgements}

We are grateful to L. Silva, M. Rodrigues, E. Rodrigues and all fisherman's for their cooperation and assistance during the field. FMS and RRSO were funded by CAPES and CNPq, respectively. MCA is funded by Postdoctoral National Fellowship addressed to the PPGEAP of UFPA (PNPD/CAPES \# 06/2017).

\section{References}

1. Barletta M, Jaureguizar AJ, Baigun C et al. Fish and aquatic habitat conservation in South America: a continental overview with emphasis on neotropical systems. Journal of Fish Biology 2010;76:2118-2176.

2. Joyeux JC, Pereira BB, De Almeida HG. The flood-tide ichthyoplanktonic community at the entrance into a Brazilian tropical estuary. Journal of Plankton Research 2004;26(11):1277-1287.

3. Pouilly M, Yunoki T, Rosales C, Trophic TL. Trophic structure of fish assemblages from Mamoré River floodplain lakes (Bolivia). Ecology of Freshwater Fish 2004;13(4):245-257.

4. Castello J. Gestão sustentável dos recursos pesqueiros, isto é realmente possível. Pan-American Journal of Aquatic Sciences 2007;2(1):47-52.

5. Barthem RB, Fabré NN. Biologia e diversidade dos recursos pesqueiros da Amazônia. A pesca e os recursos pesqueiros na Amazônia brasileira 2004;(1):17-62.

6. Silva AL. Comida de gente: Preferências e tabus alimentares entre os ribeirinhos do Médio Rio Negro (Amazonas, Brasil). Revista de Antropologia 2007;50(1):125-179.

7. Palheta MKDS, Cañete VR, Cardoso DM. Mulher e mercado: participação e conhecimentos femininos na inserção de novas espécies de pescado no mercado e na dieta alimentar dos pescadores da RESEX Mãe Grande em Curuçá (PA). Boletim do Museu Paraense Emílio
Goeldi. Ciências Humanas 2016;11(3):601-619.

8. Smith WS, Petrere JrM, Barrella, V. Fish, Sorocaba river sub-basin, state of São Paulo, Brazil. Check List 2007;3(3):282-286.

9. Mourão KRM, Ferreira V, Lucena-Frédou F. Composition of functional ecological guilds of the fish fauna of the internal sector of the amazon estuary, Pará, Brazil. Anais da Academia Brasileira de Ciências 2014;86(4):1783-1800.

10. Cardoso RS, Freitas CEDC. A pesca de pequena escala no rio Madeira pelos desembarques ocorridos em Manicoré (Estado do Amazonas), Brasil. Acta Amazonica 2008;38(4):781-787.

11. Moreno CE. Métodos para medir la biodiversidad. Volumen 1. Manuales y tesis SEA, 2001.

12. Santos Lopes GC, de Carvalho Freitas CE. Avaliação da pesca comercial desembarcada em duas cidades localizadas no rio Solimões - Amazonas. Biota Amazônia 2018;8(4):36-41.

13. Rossoni F, Ferreira E, Zuanon J. A pesca e o conhecimento ecológico local dos pescadores de acarádisco (Symphysodonae quifasciatus, Pellegrin 1904: Cichlidae) na Reserva de Desenvolvimento Sustentável Piagaçu-Purus, baixo rio Purus, Brasil. Boletim do Museu Emílio 2014;9(1):109-128.

14. Spier D, Luiz H, Gerum N, Bornatowski H, Contente R, Mattos NAS et al. Ichthyofauna of the inner shelf of Paraná, Brazil: checklist, geographic distribution, economic importance and conservation status. Biota Neotropica, 2018, 18(2).

15. Nathan AJ, Scobell A. How China Sees America: The Sum of Beijing's Fears. Foreign Aff 2012;91(5):32-47.

16. Baldisserotto B. Piscicultura continental no Rio Grande do Sul: Situação atual, problemas e perspectivas para o futuro. Ciência Rural 2009;39:291-299.

17. Ribeiro FAS, Carvalho JR, Fernandes JBK, Nakayama L. Cadeia produtiva do peixe ornamental. Panorama da Aquicultura 2009;19(1):36-45.

18. Santini F, Winterbottom R, Museum O. Historical biogeography of Indo-western Pacific coral reef biota: is the Indonesian region a centre of origin? Journal of Biogeography 2002;29(2):189-205.

19. Santarém D, Brasil P, Pereira DV, Farias L, Nolan K, Sousa S. Distribuição espacial dos sítios de captura registrados nos polos de desembarque pesqueiro no município de Santarém (Pará - Brasil). Biota Amazônia 2019;9(1):43-47.

20. Abell RA, Olson DM, Dinerstein E, Hurley PT, Diggs JT, Eichbaum W et al. Freshwater ecoregions of North America: a conservation assessment. The Quarterly Review of Biology 2001;76(2):252-253.

21. Begossi A, Clauzet M, Figueiredo JL, Garuana L, Lima $\mathrm{RV}$, Lopes PF et al. Are Biological Species and Higher-Ranking Categories Real? Fish Folk Taxonomy on Brazil's Atlantic Forest Coast and in the Amazon. Current Anthropology 2008;49(2):291-306.

22. Neto EMC, Dias CV, de Melo MN. O conhecimento ictiológico tradicional dos pescadores da cidade de Barra, região do médio São Francisco, Estado da Bahia, Brasil. Acta Scientiarum. Biological Sciences 2002;24:561-572.

23. Menezes MPM, Berger U, Mehlig U. Mangrove vegetation in Amazonia: A review of studies from the coast of Pará and Maranhão States, north Brazil. Acta Amazonica 2008;38(3):403-419. 
24. Giarrizzo T, Krumme U. Heterogeneity in intertidal fish fauna assemblages along the world's longest mangrove area in northern Brazil. Journal of Fish Biology 2008;72(3):773-779.

25. Melo TLD, Tejerina-Garro FL, Melo CED. Influence of environmental parameters on fish assemblage of a Neotropical River with a flood pulse regime, Central Brazil. Neotropical ichthyology 2009;7(3):421-428.

26. Blaber SJM, Cyrus DP, Albaret J, Ching CV, Day JW, Elliott $\mathrm{M}$ et al. Effects of fishing on the structure and functioning of estuarine and nearshore ecosystems. Journal of Marine Science 2000;57(3):590-602.

27. Beck MW, Heck KL, Able KW, Childers DL, Eggleston DB, Gillanders BM et al. The Identification, Conservation, and Management of Estuarine and Marine Nurseries for Fish and Invertebrates. Bioscience 2001;51(8):633-641.

28. Eterson ATOP. Uses and requirements of ecological niche models and related distributional models. Biodiversity Informatics 2006;3:59-72.

29. Gregório AMS, Mendes AC. Characterization of sedimentary deposits at the confluence of two tributaries of the Para River Estuary (Guajará Bay, Amazon). Continental Shelf Research 2009;29(3):609-618.

30. Kosuth P, Callède J, Laraque A, Filizola N, Guyot JL, Seyler $\mathrm{P}$ et al. Sea-tide effects on flows in the lower reaches of the Amazon River. Hydrological Processes: An International Journal 2009;23(22):3141-3150.

31. Begossi A, Clauzet M, Figueiredo JL, Garuana L, Lima RV, Lopes PF et al. Are Biological Species and Higher-Ranking Categories Real? Fish Folk Taxonomy on Brazil's Atlantic Forest Coast and in the Amazon. Current Anthropology 2008;49(2):291-306.

32. Luna Sales JB, Mehlig U, Nascimento JR et al. Análise estrutural de dois bosques de mangue do rio Cajutuba, município de Marapanim, Pará, Brasil. Boletim do Museu Paraense Emílio Goeldi-Ciências Naturais 2009;4(1):27-35.

33. Carpenter KE. The living marine resources of the western central Atlantic. FAO - Species Identification Guide for Fishery Purposes and American Society of Ichthyologists and Herpetologists Special Publication Rome, FAO 2002;5(2):601-1374.

34. Warren E. Burgess. Check list of the freshwater fishes of South and Central America. Copeia 2004;(3):714-716.

35. Marceniuk A, Caires $\mathrm{R}$, Rotundo $\mathrm{M}$ et al. The icthyofauna (Teleostei) of the Rio Caeté estuary, northeast Pará, Brazil, with a species identification key from northern Brazilian coast. Pan-American Journal of Aquatic Sciences 2017;12(1):31-79.

36. Krumme U, Saint-Paul U, Rosenthal H. Tidal and diel changes in the structure of a nekton assemblage in small intertidal mangrove creeks in northern Brazil. Aquat. Living Resour 2004;17(2):215-229.

37. Elliott M, Whitfield AK, Potter IC, Blaber SJM, Cyrus DP, Nordlie FG et al. The guild approach to categorizing estuarine fish assemblages: A global review. Fish and Fisheries 2007;8:241-268.

38. Mourão KRM, Ferreira V, Lucena-Frédou F. Composition of functional ecological guilds of the fish fauna of the internal sector of the amazon estuary, Pará, Brazil. Anais da Academia Brasileira de Ciências 2014;86(4):1783-1800.

39. Barthem RB. Ocorrência, distribuição e biologia dos peixes da Baía de Marajó, Estuário Amazônico. Boletim do Museu Paraense Emílio Goeldi, Zoologia 1985;2(1):49-69.

40. Whitfield AK, Elliott M. Fishes as indicators of environmental and ecological changes within estuaries: A review of progress and some suggestions for the future. Journal of Fish Biology 2002;61:229-250.

41. Espírito Santo RV, Isaac VJ, Abdon LMS, Martinelli JM, Higuchi H, Saint-Paul U. Peixes e Camarões do Litoral Bragantino, Pará, Brasil. Belém, Programa MADAM 2005, 268.

42. Barbosa TAP, Montag LFA. The role of Lithodoras dorsalis (Siluriformes: Doradidae) as seed disperser in Eastern Amazon. Neotropical Ichthyology 2017;15(2):110. 